\title{
PENGEMBANGAN DESTINASI WISATA PANTAI SEMBILAN KEPULAUAN GILIGENTING SUMENEP MELALUI PELATIHAN BAHASA INGGRIS KEPARIWISATAAN BAGI KELOMPOK SADAR WISATA, REMAJA DAN PEDAGANG KULINER
}

\author{
Zainollah \& Amiruddin \\ Institut Kariman Wirayudha Sumenep \\ Email: zainollah2014@gmail.com
}

\begin{abstract}
Abstrak:
Pelatihan Bahasa Inggris kepariwisataan (English for tourism) ini dilaksanakan di Wisata Pantai Sembilan Giligenting Sumenep. Pelatihan dilakukan dengan cara memberikan pendidikan Bahasa inggris kepariwisataan dalam bentuk lecturing dan practice oleh instruktur berpengalaman dari dalam dan luar negeri (native speakers). Berdasarkan analisis dan refleksi, ada lima dampak signifikan yang dihasilkan dari Pelatihan ini: (1) kesadaran masyarakat tentang pentingnya Bahasa inggris dalam pengembangan pariwisata sangat meningkat, (2) kemampuan dan keterampilan Bahasa inggris masyarakat dampingan sangat meningkat, (3) layanan informasi bagi wisatawan asing juga sangat meningkat dan lebih baik dibuktikan dengan dibentuknya pusat layanan informasi kepariwisataan (Tourism Information Center), (4) motivasi dan antusiasme belajar masyarakat dampingan juga sangat tinggi dibuktikan dengan dibentuknya kelompok diskusi dan belajar (Pantai Sembilan English Club), (5) terciptanya peluang ekonomi kreatif berbasis ekonomi wisata serta peningkatan ekonomi masyarakat melalui usaha jasa pemanduan (local tour guide) dan penukaran uang (money changer).
\end{abstract}

Kata Kunci: Destinasi, Wisata, Kepariwisataan

\begin{abstract}
s:
The English for tourism training was held at Sembilan Beach Giligenting Island Sumenep Madura. The training was conducted by educating community concerning English for tourism in form of lecturing and practice guided by experienced instructors from within and outside country (native speakers). Based on analysis and reflection, there are five significant impacts resulting from this training: (1) community awareness on importance of English in tourism development has greatly increased, (2) ability and skills of English language of assisted communities has greatly increased, (3) information services for tourists foreigners are also greatly increased and better proved by the establishment of tourism information center service (4) motivation and enthusiasm of assisted communities in learning English is also very high proved by forming English study center/club, (5) the creation of creative economic opportunities based on tourism economy as well as improving economic community through business scouting services (local tour guides) and money changers.
\end{abstract}

Key words: destination, tour, tourism 


\section{Pendahuluan}

Pembangunan dan pengembangan kepariwisataan membutuhkan dukungan dan keterlibatan banyak pemangku kepentingan (stakeholders). Pemangku kepentingan yang dimaksud meliputi tiga pihak yaitu: pemerintah, swasta dan masyarakat lokal dengan peran dan fungsinya masing-masing. Tugas dan wewenang pemerintah adalah menjalankan fungsinya sebagai fasilitator dan regulator kegiatan pembangunan kepariwisataan. Tugas pihak swasta (pelaku usaha/industry pariwisata) dengan modal dan jejaring yang dimiliki adalah menjalankan peran dan fungsinya sebagai pelaksana dan pengembang kegiatan kepariwisataan. Sedangkan tugas masyarakat dengan sumber daya yang dimiliki, baik berupa adat, tradisi, adalah sebagai tuan rumah (host) dan pelaku pengembangan kepariwisataan sesuai dengan kemampuan yang dimiliki. ${ }^{1}$

Berdasarkan uraian peran strategis pemangku kepentingan di atas, dapat disimpulkan bahwa keterlibatan tiga pemangku kepentingan tersebut menjadi keharusan dalam pengembangan kepariwisataan di Indonesia. Masing-masing pemangku kepentingan tersebut tidak bisa berjalan sendiri-sendiri dan harus selalu berdampingan dan sinergis. Jika tiga pemangku kepentingan tersebut tidak sinergis, maka pembangunan kepariwisataan tidak akan berhasil dan sukses sesuai dengan tujuan dan sasaran yang diharapkan. Oleh karena itu, pemerintah dan kalangan usaha serta swasta harus mampu menjalin hubungan atau kemitraan yang sinergi dengan masyarakat dalam hal pembangunan dan pengembangan kepariwisataan. Dengan kemitraan (partnership) yang terjalin dengan baik maka pengelolaan dan pengembangan kepariwisataan yang berbasis masyarakat (community-based tourism) akan terbentuk dan memudahkan pemerintah dalam mensukseskan agenda pembangunan kepariwisataan di Indonesia. Karena, kemajuan dan keberhasilan sebuah kepariwisataan akan ditentukan oleh seberapa besar dukungan, keterlibatan dan SDM yang dimiliki oleh masyarakat. ${ }^{2}$

Dukungan masyarakat terhadap pembangunan dan pengembangan kepariwisataan dapat diperoleh melalui penanaman kesadaran (awareness) kepada masyarakat tentang arti penting pengembangan kepariwisataan yang berbasis masyarakat. Untuk itu, maka dibutuhkan sebuah proses pengkondisian dalam rangka untuk mewujudkan masyarakat yang sadar wisata dan mengambil bagian dari kepariwisataan. Kelompok Sadar Wisata (Pokdarwis) adalah salah satu komponen dalam masyarakat yang memiliki peran dan kontribusi penting dalam pembangunan dan pengembangan kepariwisataan di daerahnya. Pokdarwis merupakan kelompok swadaya dan swakarsa masyarakat yang dalam aktivitas sosialnya bertujuan untuk meningkatkan pemahaman kepariwisataan masyarakat, meningkatkan peran dan partisipasi masyarakat dalam pembangunan kepariwisataan, meningkatkan nilai manfaat kepariwisataan bagi masyarakat dan pokdarwis, dan mensukseskan pembangunan kepariwisataan.

\footnotetext{
1 Firmansyah Rahim, Pedoman Kelompok Sadar Wisata, (Jakarta: Kementerian Pariwisata dan Ekonomi Kreatif, 2012), hlm 1.

2 Vivi Aulia, dkk, "Pelatihan Penggunaan Bahasa Inggris untuk Pariwisata (English for Tourism) bagi Siswa SMKN 4 Banjarmasin”, Jurnal Abdimas (Jurnal Pengabdian kepada Masyarakat), Vol.1, No.1 (Tahun 2017), hlm. 42.
} 
Wulandari mengemukakan bahwa diantara beberapa komponen penting dalam pengembangan destinasi wisata antara lain adalah: Atraksi dan daya tarik wisata, amenitas atau akomodasi, akseblitas dan transportasi, infrastruktur pendukung, fasilitas pendukung pariwisata serta kelembagaan dan paling penting adalah sumber daya manusia pariwisata ${ }^{3}$. Jadi, menurut pendapat di atas jelas menunjukkan bahwa masyarakat pariwisata dengan SDM yang mumpuni adalah salah satu komponen penting dalam pengembangan destinasi wisata. Masyarakat sebagai subyek dan tuan rumah harus memliki kesadaran wisata yang baik dan sumber daya yang baik dan berkualitas. Dengan sumber daya yang baik dan kesadaran wisata yang tinggi, maka pembangunan pariwisata akan semakin mudah dan berhasil.

Dintara salah satu SDM yang sangat perlu untuk ditingkatkan dalam rangka untuk menunjang proses pembangunan pariwisata adalah kemampuan memberikan pelayanan, informasi dan promosi terhadap para tamu khususnya tamu asing atau wisatawan asing. Bahasa inggris merupakan bahasa internasional yang sangat penting dan wajib untuk dikuasai oleh masyarakat sebagai alat komunikasi global khususnya menyambut dan memberikan pelayanan terhadap wisatawan asing. Aji Setyanto mengemukakan bahwa Bahasa asing dalam hal ini bahasa inggris kepariwisataan mempunyai peran penting dalam peningkatan wisata yang diantara fungsinya adalah untuk promosi wisata, pelayanan reservasi, pelayanan akomodasi (hotel atau perjalanan), pelayanan saat guiding, komunikasi wisman dengan masyarakat dan lainnya. Bahasa inggris menjadi salah satu kunci penting dalam pengembangan dan promosi destinasi wisata ke public. Bahkan, menurutnya sumber daya manusia pariwisata yang kuat dalam bidang bahasa inggris juga dapat menjadi salah satu sektor untuk menggerakkan industri pariwisata dan ekonomi kreatif masyarakat. ${ }^{4}$ Oleh karena itu, berdasarkan dua pendapat di atas, dapat ditarik kesimpulan bahwa dalam pengembangan destinasi wisata membutuhkan sumber daya manusia pariwisata yang cukup agar proses pengembangan dan pembangunan pariwisata berjalan dengan baik. ${ }^{5}$

Pulau Giligenting Sumenep merupakan salah satu kepulauan di Kabupaten Sumenep yang memiliki potensi wisata yang sangat menarik perhatian wisatawan baik dalam maupun luar negeri. Destinasi wisata di Kepulauan Giligenting Sumenep adalah Pantai Sembilan dengan keindahan pantai, pasir dan bawah lautnya. Dari sekian banyak destinasi wisata yang ada di Kabupaten Sumenep, Wisata Pantai Sembilan Giligenting merupakan destinasi wisata yang paling banyak dikunjungi oleh wisatawan asing. Menurut informasi dari pemerintah Desa Bringsang yang merupakan lokasi Wisata Pantai Sembilan bahwa dalam setiap tahun minimal ada delapan kali kunjungan kapal pesiar dengan membawa ratusan wisatawan asing dari berbagai negara. Selain kunjungan kapal pesiar, wisatawan asing juga hampir setiap miggu berkunjung ke Pantai Sembilan untuk menikmati pantai, pasir dan

\footnotetext{
${ }^{3}$ Listiani Warih Wulandari, "Pengembangan Pariwisata Ekonomi Kreatif Desa Wisata Berbasis Budaya sebagai Niche Market Destination (Studi Kasus Pengembangan Desa Wisata di Kabupaten Sleman)", Jurnal Aplikasi Bisnis, Vol. 16, No. 09 (Januari 2014), hlm. 42.

${ }^{4}$ Aji Setyanto, Pentingnya Penguasaan Bahasa dan Budaya Asing Sebagai Pendukung Utama Sektor Pariwisata, (Malang: Univesitas Brawijaya, 2015) Hlm. 1.

${ }^{5}$ Moh Wardi, Pengembangan entrepreneurship berbasis experiential learning di pesantren Al-Amien Prenduan Sumenep dan Darul Ulum Banyuanyar Pamekasan. Diss. UIN Sunan Ampel Surabaya, 2017.
} 
keindahan bawah laut kepulauan Giligenting Sumenep. Berdasarkan penelusuran peneliti, pada prinsipnya edukasi Sadar Wisata oleh Kelompok Sadar Wisata sudah berjalan dengan baik meskipun perlu untuk melakukan peningkatan dengan model edukasi wisata yang lebih baik, kreatif dan inovatif.

Berdasarkan penelusuran peneliti di lapangan dengan mewawancarai pemerintah dan masyarakat setempat, pelaksanaan pengembangan pariwisata di Kepulauan Giligenting Sumenep masih belum maksimal. Masyarakat dan pengelola wisata masih belum mampu memberikan pelayanan yang baik dan mengesankan kepada wisatawan asing dikarenakan terkendala lemahnya Sumberdaya Manusia tentang bahasa inggris kepariwisataan. Masalah-masalah yang terjadi di masyarakat diantaranya adalah sebagai berikut:

Pertama, Kelompok sadar wisata, remaja dan pedagang kuliner di lokasi pantai Giligenting masih sangat minim kemampuan dan keterampilan berbicara bahasa inggris khususnya tentang kepariwisataan. Sehingga, mereka merasa kesulitan ketika berinterkasi dengan wisatawan asing baik ketika diminta layanan informasi, transaksi dan lainnya. Kedua, Sering terjadi kesan atau kenangan yang tidak baik ketika wisatawan asing berkunjung ke Wisata Pantai Sembilan Giligenting Sumenep tanpa membawa pemandu pribadi disebabkan karena kesulitan berinterkasi dengan masyarakat penjual kuliner dan produk khas daerah di lokasi wisata. Menurut informasi, wisatawan sering merasa kecewa dengan pelayanan masyarakat karena banyak masyarakat dan pedagang tidak mampu berkomunikasi dengan menggunakan bahasa inggris dasar, sederhana dan bisa dimengerti. Padahal, dalam pembangunan dan pengembangan pariwisata, memberikan kesan dan kenangan yang baik bagi wisatawan adalah kewajiban masyarakat sesuai dengan program Kementerian Pariwisata Republik Indonesia yang termaktub dalam SAPTA PESONA.

Ketiga, Di sekitar lokasi Wisata Pantai Sembilan Giligenting Sumenep belum terdapat layanan pemandu wisata berbasis masyarakat local (local tour guide) khusus wisatawan asing yang dikelola oleh masyarakat dan kelompok sadar wisata. Wisatawan yang datang justru dimanfaatkan oleh orang luar daerah Kabupaten Sumenep. Hal ini sebenarnya menjadi peluang alternatif bagi masyarakat dan pokdarwis untuk mengembangkan dan membangun pariwisata dari sektor ekonomi wisata kreatif dengan membentuk jasa biro perjalanan wisata dan pemandu wisata untuk meningkatkan kesejahteraan ekonomi masyarakat. Padahal ekonomi kreatif merupakan salah satu penggerak industri pariwisata dan sumber daya manusia merupakan pilar utama tumbuh dan berkembangnya ekonomi kreatif di Indonesia. ${ }^{6}$ Keempat, Masyarakat, remaja, pokdarwis, penjual kuliner, kerajinan dan produk khas daerah yang ada di titik lokasi Wisata pantai Sembilan masih mempunyai anggapan bahwa bahasa inggris masih tidak terlalu penting untuk pengembangan dan pembangunan kepariwisataan. Padahal bahasa inggris merupakan bahasa yang sangat penting untuk dikuasai untuk mengembangkan destinasi wisata.

Oleh karena itu, berdasarkan latar belakang di atas, maka perlu kiranya untuk memberikan pelatihan atau pendidikan bahasa inggris kepariwisataan kepada

\footnotetext{
${ }^{6}$ Rochmat Aldi Purnomo, Ekonomi Kreatif: Pilar Pembangunan Ekonomi Indonesia, (Surakarta: Ziyad Visi Media, 2016), hlm 48.
} 
masyarakat di Kepulauan Giligenting Sumenep sebagai upaya untuk menunjang kegiatan pariwisata di Kepulauan Giligenting Sumenep. Peneliti/pengabdi tertarik untuk melakukan pengabdian kepada masyarakat dengan cara memberikan pelatihan kepada Kelompok Sadar Wisata dan Remaja tentang bahasa inggris kepariwisataan untuk mengembangkan destinasi wisata Pantai Sembilan Giligenting Sumenep Madura.

\section{Metode Pelaksanaan}

Pendekatan yang digunakan dalam pengabdian berbasis riset ini adalah riset aksi partisipatif atau yang popular dengan istilah Participatory Action Research (PAR). Menurut Cresswell Participatory Action Research (PAR) atau kaji tindak partisipatif adalah sebuah metode penelitian tindakan yang tujuan utamanya adalah untuk memperbaiki kualitas kehidupan masyarakat (community), organisasi atau kelompok (organization) dan sebuah keluarga (family). ${ }^{7}$ Dalam penelitian aksi partisipatif, masyarakat dituntut dan didorong untuk aktif dalam memperbaiki kehidupan mereka sendiri. Dengan kata lain, dalam PAR masyarakat (community) adalah sebagai subyek penelitian bukan obyek. Hal ini yang kemudian menjadi dasar lahirnya pendekatan penelitian PAR yaitu sebagai kritik terhadap kegiatan penelitian konvensional yang menjadikan masyarakat sebagai obyek penelitian. PAR merupakan penelitian yang melibatkan secara aktif semua pihak-pihak yang relevan (stakeholders) dalam mengkaji tindakan yang sedang berlangsung (di mana pengamalan mereka sendiri sebagai persoalan) dalam rangka melakukan perubahan dan perbaikan ke arah yang lebih baik. Dalam pelaksanaannya, teknik dan tahapan pengabdian diringkas dengan tahapan sebagai berikut:

\section{Perencanaan kegiatan}

Tahap pertama dalam kegiatan pengabdian ini perencanaan dan persiapan. Pada tahap ini, peneliti atau pengabdi melakukan penguatan data, komunikasi dan koordinasi dengan beberapa stakeholder yang terlibat dalam kegiatan ini seperti pemerintah desa dan perangkatnya, tokoh masyarakat dan Kelompok Sadar Wisata untuk mempersipkan segala sesuatu yang dibutuhkan dalam kegiatan pengabdian seperti ijin pelaksanaan kegiatan, tempat pelaksanaan, waktu pelaksanaan, peserta kegiatan dan lain-lain. Tahapan kedua adalah melakukan sosialisasi kepada masyarakat sekitar kawasan Wisata Pantai Sembilan, khususnya Kelompok Sadar Wisata, Remaja dan para pedagang kuliner terkait rencana pelaksanaan kegiatan pelatihan bahasa inggris kepariwisataan sebagai upaya untuk mengembangkan kegiatan pariwisata di Wisata Pantai Sembilan Giligenting Sumenep. Tujuan dari kegiatan sosialisasi ini dalam rangka untuk menghimpun peran serta masyarakat dalam pelaksanaan program pengabdian agar kegiatan pengabdian berjalan dengan baik, maksimal dan sukses sesuai dengan persiapan dan perencanaan.

\section{Pelaksanaan Kegiatan}

\footnotetext{
7 John W. Cresswell, Educational Research (Planning, Conducting and Evaluating Qualitative and Quantitative Research), (USA: Pearson Education, 2012) HIm. 582
} 
Setelah persiapan kegiatan dilakukan yang meliputi perijinan, tempat pelaksanaan kegiatan, waktu, jadwal dan durasi pelaksanaan kegiatan, pemilihan atau penentuan peserta kegiatan dan materi kegiatan, tahapan selanjutnya yang akan dilakukan adalah pelaksanaan kegiatan pelatihan bahasa inggris kepariwisataan kepada Kelompok Sadar Wisata, Remaja dan Pedagang kuliner di lokasi Wisata Pantai Sembilan Giligenting Kabupaten Sumenep. Dalam pelaksanaan kegiatan, rencana pelaksanaan kegiatan dapat digambarkan sebagai berikut:

Pertama, memberikan pendidikan bahasa inggris kepariwisataan dalam bentuk pelatihan dan short course kepada Kelompok Sadar Wisata yang dipimpin oleh pengabdi dan dibantu oleh beberapa pelatih khusus (pakar/ahli) dalam bidang pendidikan bahasa inggris kepariwisataan. Kedua, Selain memberikan pelatihan atau kursus bahasa inggris kepariwisataan, dalam rangka menguatkan pemahaman dan motivasi atau semangat pengembangan kepariwisataan masyarakat, pemuda, pedagang kuliner dan Kelompok Sadar Wisata, peneliti juga melibatkan memberikan penyuluhan atau Seminar Pengembangan Kepariwisataan kepada masyarakat Kepulauan Giligenting Sumenep.

Luaran yang diharapkan dari pelaksanaan kegiatan ini adalah: (1) Membentuk Kelompok Sadar Wisata, Masyarakat, Remaja dan para pedagang di kawasan Wisata Pantai Sembilan memiliki kemampuan berbahasa inggris yang baik dan lancar yang dapat digunakan dalam pengembangan pariwisata seperti pelayanan terhadap wisatawan asing dan media promosi. (2) Terbentuknya wadah atau kelompok dan pusat layanan informasi yang mampu berkomunikasi bahasa inggris dengan tamu atau wisatawan asing. (3) Terbentuknya kelompok atau pemandu wisata lokal (local tour guide) yang melayani tamu atau tourist dari berbagai Negara sehingga dapat menjadi usaha ekonomi kreatif masyarakat dalam meningkatkan kesejahteraan ekonomi mereka. (4) Masyarakat juga diharapkan memiliki pengetahuan kepariwisataan dan skill pelayanan yang baik sebagai upaya menunjang pengembangan dan pembangunan kegiatan pariwisata di Giligenting Sumenep.

\section{Pendampingan dan Pengembangan}

Tahapan berikutnya adalah kegiatan pendampingan dan pengembangan masyarakat. Kegiatan ini dilakukan untuk menjaga kelangsungan kegiatan atau program yang sudah dilakukan. Pengembangan ini dilakukan dengan cara: (1) Memberikan pembinaan dan bimbingan dengan memberikan materi bahasa inggris tambahan (update) sesuai dengan kebutuhan dan perkembangan terbaru bahasa inggris kepariwisataan di Indonesia. (2) Memberikan layanan konsultasi dalam setiap persoalan yang dihadapi masyarakat di lapangan yang berkaitan dengan bahasa inggris kepariwisataan dan pengembangan kepariwisataan dalam bentuk kunjungan dan online. (3) Melakukan kunjungan atau monitoring pelaksanaan pengembangan pariwisata melalui penggunaan bahasa inggris kepariwisataan di Wisata Pantai Sembilan Giligenting Sumenep. (4) Membantu mensosialisasikan kegiatan dan promosi kegiatan pengembangan pariwisata masyarakat melalui media sosial dan lain-lain.

\section{Hasil dan Pembahasan}

1. Pelaksanaan 
Pelaksanaan pelatihan dilakukan dengan cara memberikan pendidikan Bahasa inggris kepariwisataan kepada subyek dampingan dalam bentuk pembelajaran yang dilakukan selama 16 kali pertemuan. Alokasi waktu pelatihan Bahasa inggris kepariwisataan adalah 180 menit dalam setiap pertemuan. Dalam setiap pertemuan, peneliti bersama tim tidak hanya menguatkan keilmuan dalam bentuk ceramah dan pembelajaran (class sessions) akan tetapi juga dalam bentuk praktek langsung di lapangan (outdoor class and practice). Tidak hanya itu, pengembangan kemampuan dan keterampilan juga dilakukan dengan praktek langsung dengan penutur Bahasa inggris asli (Native Speakers) dari Inggris dan Amerika. Selain itu praktek juga dilakukan dengan turis dari berbagai negara seperti: Jerman, Belanda, Switzerland, Perancis, Australia, dan Negara Asia, Amerika dan Eropa lainnya. Instruktur dalam pelatihan ini adalah Tim Peneliti dan dibantu oleh pakar dalam bidang Pendidikan Bahasa Inggris dari berbagai PTKI dan PTKIS di Pulau Madura.

\section{Hasil Pemberdayaan}

Sebagaimana dijelaskan di awal bahwa landasan utama dilaksanakannya Pelatihan Bahasa Inggris Kepariwisataan ini adalah riset partisipatif yang dilakukan bersama masyarakat Bringsang Giligenting Sumenep. Hasil riset partisipatif menunjukkan bahwa Destinasi Wisata Pantai Sembilan Giligenting Sumenep dalam pengembangannya membutuhkan sumberdaya manusia yang mempunyai keterampilan bahasa Inggris kepariwisataan (English for Tourism) dikarenakan tingginya kunjungan wisatawan asing ke Pantai Sembilan setiap tahun sehingga membuat pengelola wisata (pokdarwis dan remaja) serta pedagang yang ada di lokasi wisata merasa kebingungan dan kesulitan dalam berkomunikasi dan memberikan pelayanan informasi kepariwisataan kepada wisatawan asing. Sulitnya berkomunikasi dengan wisatawan asing dapat berdampak buruk terhadap pengembangan destinasi wisata karena dapat menimbulkan kesan tidak baik terhadap wisatawan serta bisa berdampak terhadap menurunnya jumlah kunjungan wisatawan asing ke Pantai Sembilan.

Menurut data yang peneliti dapatkan dari masyarakat dan pemerintah Desa Bringsang jumlah kunjungan wisatawan asing dengan menggunakan Kapal Pesiar (Cruiser) kurang lebih sekitar 1.500 orang sedangkan wisatawan asing regular berkisar 200 orang sehingga jumlah total kunjungan wisatawan asing setiap tahun kurang lebih sebanyak 1.700 orang. Dari data tersebut menunjukan bahwa daya tarik Wisata Pantai Sembilan cukup tinggi sehingga pengembangan dan pelayanan yang baik bagi wisatawan asing sangat diperlukan agar jumlah kunjungan wisatawan asing semakin meningkat setiap tahunnya. Oleh karena itu, pelaksanaan Pelatihan Bahasa Inggris Kepariwisataan bagi subyek dampingan diharapkan memberikan perubahan dan menjadi solusi pemecahan masalah subyek dampingan di Destinasi Wisata Pantai Sembilan Kecamatan Giligenting Sumenep.

Berdasarkan refleksi dan analisis yang dilakukan peneliti dan tim serta subyek dampingan, ada banyak perubahan signifikan dan hasil dari Pelatihan Bahasa Inggris Kepariwisataan yang sudah dilakukan. Perubahan ini diharapkan menjadi bekal dan solusi bagi subyek dampingan untuk terus melakukan pengembanganpengembangan khsusnya pelayanan terhadap wisatawan asing yang berkunjung ke 
Pantai Sembilan Desa Bringsang Kecamatan Giligenting Kabupaten Sumenep. Perubahan-perubahan tersebut dapat peneliti uraikan sebagai berikut:

\section{Peningkatan kesadaran}

Perubahan pertama yang dihasilkan dari kegiatan Pelatihan Bahasa Inggris Kepariwisataan ini adalah meningkatnya kesadaran masyarakat dalam hal ini subyek dampingan tentang pentingnya bahasa Inggris kepariwisataan. Sebelum pelatihan ini dilakukan kesadaran masyarakat tentang pentingnya bahasa inggris sangatlah rendah dan minim sehingga mereka perlu diberikan pendidikan dan penyadaran agar kesadaran mereka semakin meningkat. Peneliti bersama tim serta para narasumber memberikan penyuluhan kepada subyek dampingan yang tujuannya tidak lain untuk meningkatkankan percaya diri, motivasi dan kesadaran masyarakat tentang pentingnya bahasa inggris dalam dunia pariwisata. Selain itu dalam setiap pertemuan-pertemuan penyemapian materi pelatihan, peneliti bersama tim dan dibantu oleh beberapa pihak khususnya pelaku wisata yang ada seperti owner Madura Vacation tidak henti-hentinya untuk terus melakukan edukasi kepada masyarakat tentang pentingnya bahasa inggris dalam pengembangan pariwisata.

Hasil dari edukasi melalui seminar dan penyuluhan, pelatihan serta pendampingan secara intensif oleh peneliti dan tim kesadaran subyek dampingan mengalami penigkatan yang sangat signifikan. Mereka memiliki kesadaran yang tinggi bahwa bahwa bahasa inggris merupakan bahasa internasional yang sangat penting sebagai bahasa komunikasi global (means of global communication).

\section{Peningkatan pengetahuan dan keterampilan}

Perubahan yang juga sangat signifikan bagi subyek dampingan dengan adanya Pelatihan Bahasa Inggris Kepariwisataan adalah adanya peningkatan pengetahuan dan keterampilan tentang Bahasa Inggris Kepariwisataan (English for Tourism). Sebagaimana dijelaskan diawal, bahwa kelompok sadar wisata, remaja dan pedagang yang ada di lokasi Wisata Pantai Sembilan Giligenting Sumenep tidak mempunyai pengetahuan sama sekali tentang bahasa inggris kepariwisataan hal ini disebabkan karena minimnya kesadaran, motivasi dan tidak adanya pendidikan dan pelatihan khusus bagi masyarakat di lokasi wisata Pantai Sembilan. Akibatnya, mereka sangat kesulitan berkomunikasi bahasa inggris dengan wisatawan asing (tourist) ketika sedang dimintai informasi seputar wisata dan ketika melakukan transaksi jual beli. Pengelola wisata tidak mampu memberikan informasi kepariwisataan jika dimintai informasi oleh wisatawan asing serta tidak ada pusat layanan informasi khususu bagi wisatawan asing. Sedangkan pedagang yang ada di lokasi Wisata Pantai Sembilan juga menggunakan bahasa isyarat dengan menggunakan tangan dan menulis setiap harga barang yang akan dibeli oleh wisatawan asing. Apa yang sudah dilakukan oleh pengelola dan pedagang ini dianggap sangat kurang baik dan efektif karena masih sering terjadi kesalah pahaman antara pengelola atau pedagang dan wisatawan asing dan berkesan kurang baik. Oleh karena itu, Pelatihan Bahasa Inggris Kepariwisataan merupakan solusi permasalahan mereka.

Pelatihan Bahasa Inggris Kepariwisataan yang diberikan kepada pedagang di lokasi Wisata Pantai Sembilan sangat bermanfaat dan memberikan perubahan yang 
sangat positif. Dengan adanya pelatihan ini subyek dampingan mempunyai pengetahuan tentang dasar-dasar bahasa inggris dan terampil dalam berkomunikasi dengan wisatawan asing ketika dimintai informasi dan melakukan transaksi jual beli. Selama proses pengabdian ini dilaksanakan, ada sekitar 4 kali kunjungan kapal pesiar ke Pantai Sembilan tepatnya pada tanggal 19 Agustus 2019, 2, 16 dan 25 September 2019. Dalam setiap kunjungan ada sekitar 150 wisatawan asing dengan menggunakan Kapal Pesiar Star Clipper dan berkunjung ke Pantai Sembilan. Momen tersebut kemudian menjadi momen penting pembuktian dan praktek mereka setelah mendapatkan materi bahasa inggris. Alhamdulillah subyek dampingan mampu berkomunikasi dan bertransaksi dengan menggunakan bahasa inggris dengan wisatawan dengan didampingi peneliti. Bahasa inggris yang mereka pelajari sangat bermanfaat dan membawa perubahan nyata dalam pengalaman dan kehidupan mereka.

\section{Peningkatan layanan informasi (Tourism Information Center)}

Perubahan yang dihasilkan setelah pelaksanaan Pelatihan Bahasa Inggris Kepariwisataan lainnya adalah adanya upaya peningkatan pelayanan terhadap wisatawan asing (tourist) yang berkunjung ke Wisata Pantai Sembilan. Peningkatan pelayanan tersebutkan dibuktikan dengan dibentuknya Tourism Information Center (TIC) atau pusat layanan informasi kepariwisataan. TIC merupakan posko pelayanan informasi bagi wisatawan asing yang dibentuk oleh pengelola wisata dengan tujuan untuk memberikan informasi penting yang dibutuhkan oleh wisatawan asing seperti petunjuk arah, tradisi dan kebudayaan, destinasi wisata di Sumenep dan lain semacamnya dengan menggunakan bahasa inggris. Posko layanan informasi ini sangat bermanfaat bagi subyek dampingan sebagai media praktek dan pengembangan kemampuan dan keterampilan bahasa inggris mereka.

\section{Peningkatan motivasi dan antusiasme belajar}

Perubahan lain yang dihasilkan dari pelaksanaan Pelatihan Bahasa Inggris Kepariwisataan adalah meningkatnya motivasi dan antusiasme belajar bahasa inggris kelompok sadar wisata, remaja dan pedagang. Setiap pertemuan dengan subyek dampingan, tim peneliti dan pelatih tidak bosan-bosan untuk selalu memberikan motivasi kepada subyek dampingan tentang pentingnya bahasa inggris dalam pengembangan destinasi wisata Pantai Sembilan. Hal itu kemudian membuat antusiasme dan motivasi belajar subyek dampingan semakin kuat dan meningkat.

Peningkatan motivasi dan antusiasme belajar ini diakui oleh beberapa pihak yang turut serta mengamati pelaksanaan Pelatihan Bahasa Inggris Kepariwisataan khususnya Pemerintah Desa Bringsang. Mereka mengatakan bahwa anstusiasme subyek dampingan sangat meningkat semenjak adanya Pelatihan Bahasa Inggris Kepariwisataan hal itu ditunjukkan oleh sikap dan perilaku subyek dampingan ketika berkumpul dan bertemu di pantai dengan saling menyapa dengan menggunakan bahasa inggris semampunya meskipun masih terdapat banyak kekurangan dan kesalahan. Akan tetapi itu sudah menunjukan bahwa mereka sudah memiliki percaya diri dan semangat yang sangat luar biasa.

Dengan antusiasme dan motivasi yang kuat tersebut kemudian subyek dampingan mengusulkan agar dibentuk kelompok belajar bahasa inggris atau komunitas sebagai media dan wadah belajar sekaligus pengembangan keilmuan 
subyek dampingan tentang bahasa inggris kepariwisataan. Peneliti bersama tim sangat merespon baik usulan tersebut sebagai upaya untuk menjaga motivasi dan antusiasme dan mengembangkan pengetahuan dan keterampilan bahasa inggris subyek dampingan. Subyek dampingan dan peneliti berdiskusi dan bermusyawarah tentang rencana pembentukan komunitas dan kelompok belajar tersebut dan pada akhirnya disepakati untuk membentuk sebuah kelompok belajar bahasa inggris dengan nama Pantai Sembilan English Community (PSEC). Pada saat itu pula disepakati dan ditunjuk ketua kelompok belajar yaitu Mr. Syamsul Arifin dan Mr. Miskali. Tidak hanya itu, untuk mengembangkan dan meningkatkan pengetahuan bahasa inggris para peserta subyek dampingan, subyek dampingan juga menyepakati untuk membuat group Whatssup sebagai media komunikasi dan konsultasi bahasa.

\section{Peningkatan Peluang Usaha Alternatif dan Ekonomi Kreatif}

Pelatihan Bahasa Inggris yang sudah peneliti lakukan bersama masyarakat tidak hanya memberikan dampak yang signifikan terhadap kesadaran terhadap pengembangan destinasi wisata, motivasi dan antusiasme belajar, serta pelayanan terhadap wisatawan asing akan tetapi pendidikan Bahasa inggris kepariwisataan bagi kelompok sadar wisata, remaja dan pedagang kuliner ini juga berdampak signifikan terhadap peningkatan peluang usaha dan ekonomi masyarakat yang berbasis ekonomi wisata kreatif. Dengan berbekal pengetahuan yang sangat dasar tentang Bahasa inggris praktif kepariwisataan, subyek dampingan mampu membaca dan mencari peluang alternatif melalui pengetahuan Bahasa inggris yang dimiliki untuk meningkatkan ekonomi dan kesejahteraan masyarakat. Peluang usaha yang ditemukan dan dimanfaatkan adalah menjadi pemandu wisata local (local tour guide) bagi wisatawan asing yang hendak menjelajahi kepualuan Giligenting.

Setiap ada kunjungan kapal pesiar (Star Clipper), tidak sedikit wisatawan asing yang meminta sebagian pengelola pantai untuk menyediakan jasa pemanduan kepada wisatawan dengan mengantarkan mereka para wisatawan berkeliling di Kepulauan Giligenting dengan menggunakan sepeda motor (scooter), akan tetapi para pengelola dan masyarakat banyak yang tidak bersedia karena tidak mampu dan terampil berbicara Bahasa inggris. Akan tetapi, setelah dilaksanakannya pelatihan dan pendidikan Bahasa inggris kepariwisataan ini, subyek dampingan mulai berani, percaya diri dan mampu menawarkan jasa pemanduan kepada wisatawan (tourist) tanpa harus diminta atau ditanya oleh wisatawan meskipun kemampuan bahasa inggrisnya masih diperlukan perbaikan dan pengembangan.

Adanya jasa pemanduan ini berdampak terhadap pendapatan dan ekonomi masyarakat karena jasa pemanduan ini tidak gratis. Para wisatawan harus membayar sesuai dengan kesepakatan, jarak titik yang akan dikunjungi dan durasi waktu perjalanan. Umumnya, biaya keliling pulau Giligenting dengan menggunakan scooter biayanya sekitar 150.000-200.000 per-scooter. Harga ini sangat murah bagi wisatawan bahkan dalam pelaksanaannya wisatawan sering membayar lebih bahkan sampai 300.000 karena mereka sangat senang dan puas dengan perjalanan dan lokasi yang dikunjungi. Titik yang biasa diminta untuk dikunjungi adalah perumahan atau pemukiman warga, pasar dan Pantai Kahuripan yang juga tidak jauh dari Pantai Sembilan. Selain usaha pemanduan, subyek dampingan juga ada 
yang menyediakan jasa penukaran uang (money changer) bagi wisatawan asing. Dengan pengetahuan Bahasa inggris dasar seperi English for vendors (questions, numerals, etc), subyek dampingan mampu melayani wisatawan ketika ada yang ingin menukar uang baik dollar maupun rupiah.

Data analisis dampak dan perubahan di atas menunjukkan bahwa Pelatihan Bahasa Inggris Kepariwisataan bagi kelompok sadar wisata, remaja dan pedagang kuliner adalah solusi pemecahan masalah masyarakat dampingan. Pelatihan yang sudah peneliti lakukan memberikan kontribusi dan perubahan besar bagi masyarakat dampingan khususnya dalam pengembangan pelayanan destinasi wisata pantai Sembilan dan kesejahteraan ekonomi masyarakat. Sebagaimana dijelaskan di awal bahwa pelayanan kepada wisatawan asing di lokasi wisata Pantai Sembilan sangat tidak baik yang disebabkan oleh minimnya masyarakat, pengelola dan pelaku wisata yang memiliki pengetahuan dan keterampilan Bahasa inggris kepariwisataan sehingga membuat mereka kesulitan berinteraksi dan memberikan pelayanan informasi kepariwisataan. Pelatihan Bahasa inggris yang sudah dilakukan memberikan perubahan besar bagi masyarakat utamanya peningkatan pengetahuan dan keterampilan Bahasa inggris kepariwisataan masyarakat yang bisa digunakan sebagai faktor penunjang pengembangan pelayanan. Tidak hanya itu, dengan kemampuan dan keterampilan Bahasa inggris praktis kepariwisataan yang dimiliki oleh subyek dampingan, mereka semakin kreatif menemukan peluang usaha alternatif dengan memanfaatkan kemampuan Bahasa inggris yaitu sebagai pemandu lokal (local guides) dan layanan penukaran uang (money changer).

Keilmuan dan pengetahuan peserta dalam pelatihan Bahasa inggris sangat dinamis, komunikatif dan interaktif karena memang proses pembelajaran disajikan dengan pendekatan yang menuntut peserta bekerja kelompok dan komunikatif dengan menekankan pada aspek praktek langsung di dunia nyata. Apa yang peneliti lakukan ini tidak lepas dari teori yang dikemukakan oleh Larsen-Freeman dalam pembelajaran bahasa inggris yaitu pendekatan audio-lingual method yang dikombinasikan dengan pendekatan komunikatif dan kooperatif sebagaimana yang telah dikembangkan oleh Littlewood. Kombinasi pendekatan sangat efektif untuk mencapai target pelatihan bahasa inggris kepariwisataan yang sifatnya praktis. Pendekatan audio-lingual method berfungsi untuk membentuk kebiasaan melalui teknik drillnya (latihan); yakni penekanan pada audio-lingual yaitu latihan mengidentifikasi bunyi sampai pada pemahaman secara otomatis terhadap utterance yang disampaikan.

Lebih lanjut Little wood juga mengemukakan bahwa dalam proses belajar bahasa inggris tidak lepas pula dari konteks dan situasi; kadang kala suatu tuturan menimbilkan makna baru yang disebut dengan pragmatik. Konteks ini harus pula dipahami dan dimengerti oleh pembelajar bahasa. Untuk itu situasi dan konteks nyata harus pula menjaadi bagian yang tidak terpisahkan dengan pembelajaran bahasa. Di sinilah fasilitator dituntut memiliki daya cipta merancang materi pletihan yanga kreatif, dan dapat mengantarkan trainee mampu berkomunikasi dan berinteraksi. Berkenan dengan tujuan pelatihan ini maka pendekatan kombinatif pelatihan sangat tepat dimanfaatkan dalam pelatihan Bahasa inggris praktis. 


\section{Penutup}

Berdasarkan pembahasan di atas, kegiatan pemberdayaan ini dapat disimpulkan sebagai berikut:

Pertama, pelaksanaan pelatihan dilakukan dengan cara memberikan pendidikan Bahasa inggris kepariwisataan kepada subyek dampingan dalam bentuk pembelajaran yang dilakukan selama 16 kali pertemuan. Dalam setiap pertemuan, peneliti bersama tim tidak hanya menguatkan keilmuan dalam bentuk ceramah dan pembelajaran (class sessions) akan tetapi juga dalam bentuk praktek langsung di lapangan (outdoor class and practice). Tidak hanya itu, pengembangan kemampuan dan keterampilan juga dilakukan dengan praktek langsung dengan penutur Bahasa inggris asli (Native Speakers) dari Inggris dan Amerika. Selain itu praktek juga dilakukan dengan turis dari berbagai negara seperti: Jerman, Belanda, Switzerland, Perancis, Australia, dan Negara Asia, Amerika dan Eropa lainnya.

Kedua, dampak dari pelaksanaan pelatihan Bahasa inggris kepariwisataan ini sangat signifikan terhadap pengembangan destinasi wisata Pantai Sembilan Giligenting Sumenep. Dari analisis yang peneliti dan subyek dampingan lakukan, setidaknya ada lima dampak signifikan yang dihasilkan dari pelaksanaan pelatihan Bahasa inggris kepariwisataan ini: (1) peningkatan kesadaran masyarakat terhadap pentingnya belajar Bahasa inggris kepariwisataan untuk mengembangan destinasi wisata pantai Sembilan, (2) peningkatan kemampuan dan keterampilan Bahasa inggris masyarakat dampingan, (3) peningkatan layanan informasi bagi wisatawan asing yang dibuktikan dengan dibentuknya pusat layanan informasi kepariwisataan (Tourism Information Center), (4) peningkatan motivasi dan antusiasme belajar masyarakat dampingan dibuktikan dengan dibentuknya kelompok diskusi dan belajar (Pantai Sembilan English Club), (5) adanya peluang ekonomi kreatif dan peningkatan ekonomi masyarakat melalui jasa pemandu wisata local (local tour guide) dan penukaran uang (money changer) yang dilakukan oleh masyarakat di area pantai sembilan.

\section{Daftar Pustaka}

Azhari \& Roslina. Bahasa Inggris Pariwisata Di Desa Wisata Tangkeno. Paper Hasil Penelitian. Universitas Sembilanbelas November Kolaka. 2015

Aulia, Vivi, dkk. Pelatihan Penggunaan Bahasa Inggris untuk Pariwisata (English for Tourism) bagi Siswa SMKN 4 Banjarmasin. Jurnal Abdimas (Jurnal Pengabdian kepada Masyarakat), Vol.1, No.1. 2017

Ali, Moh. Humaidi. Mengenal PAR dan PRA. Yogyakarta: Pustaka Nusantara. 2013

Creswell, John W. Educational Research: Planing, Conducting and Evaluating Quantitative and Qualitative Research. USA: Pearson Education Inc. 2012

Direktorat Jenderal Pengembangan Destinasi Pariwisata, Kementerian Pariwisata dan Ekonomi Kreatif. Buku Pedoman Kelompok Sadar Wisata. Jakarta. Kemenpar dan Ekonomi Kreatif RI. 2012

Gray, David E. Doing Research in the Real World. London: Sage Publication. 2004

Ken McIntyre. English for Tourism. Dili: Dili Institute of Technology, Timor Leste. 2013 
McNiff, Jean. Action Research (Principles and Practice) Third Edition. Routledge Falmer:2002

Mclntyre, Alice. Participatory Action Research (Qulitative Research Series). Sage Publication:2008

Oka A. Yoeti. Pengantar Ilmu Pariwisata. Bandung: Angkasa. 1993

Suwantoro. Dasar-dasar Pariwisata. Andi: Yogyakarta. 2002

Purnomo, Rochmat Aldi. Ekonomi Kreatif: Pilar Pembangunan Ekonomi Indonesia. Surakarta: Ziyad Visi Media. 2016

Rahim, Firmansyah. Pedoman Kelompok Sadar Wisata. Jakarta: Kementerian Pariwisata dan Ekonomi Kreatif. 2012

Setyanto, Aji. Pentingnya Penguasaan Bahasa dan Budaya Asing Sebagai Pendukung Utama Sektor Pariwisata. Malang: Univesitas Brawijaya. 2015

Stringer, Ernest T. Action research (Third Edition). Sage Publication: 2007

Tacchi, Slater, Hearn. Etnographic Action Research. New Delhi: UNESC0.2003

Fraenkel, Jack R. and Wallen E Norman. Design and Evaluate Research in Education. New York: Beith Mejia. 2009

Wulandari, Listiani Warih. Pengembangan Pariwisata Ekonomi Kreatif Desa Wisata Berbasis Budaya sebagai Niche Market Destination (Studi Kasus Pengembangan Desa Wisata di Kabupaten Sleman". Jurnal Aplikasi Bisnis, Vol. 16, No. 09. 2014)

Wardi, Moh. Pengembangan entrepreneurship berbasis experiential learning di pesantren Al-Amien Prenduan Sumenep dan Darul Ulum Banyuanyar Pamekasan. Diss. UIN Sunan Ampel Surabaya, 2017.

Zainollah, Mengenal Dasar-Dasar PAR dan PRA, Sumenep: Kariman Press, 2016 